\title{
Tourism Village Innovation: Accelerating The Improvement of The Local Finance Through The Exploration of Local Wisdom
}

\author{
Fitrotun Niswah ${ }^{1}$, Eva Hany Fanida ${ }^{2}$, Trenda Aktiva Oktarianda ${ }^{3}$ \\ \{fitrotunniswah@unesa.ac.id ${ }^{1}$,evafanida@unesa.ac.id ${ }^{2}$,Trendaaktiva@gmail.com ${ }^{3}$ \} \\ Departement of Public Administration, Universitas Negeri Surabaya, Indonesia ${ }^{1}$ \\ Departement of Public Administration, Universitas Negeri Surabaya, Indonesia ${ }^{2}$ \\ Departement of Public Administration, Universitas Negeri Surabaya, Indonesia ${ }^{3}$
}

\begin{abstract}
The tourism sector has great potential in Indonesia. Tourism is the most contributor to GDP, foreign exchange and employment. tourism is an developed as a form of national development that can improve the local finance and empower the society. The urgency, then each village has a variety of tourism village concepts that are packaged according to their attractiveness. including educational villages, nature tourism, agricultural center, plantations, craft center and many others. to realized the concept must be collaboration with all element including the following to manage promote with social media, and the selling platform on the Digital Market Place to create an innovative village based on a prosperous, religious community by utilizing the potential of nature, cultural arts and local crafts. for this reason, the development of the potential of a Tourism Village is a strategic step to build and improve the local finance rural.
\end{abstract}

Keywords: Tourism Village Innovation, Local Finance, Local Wisdom

\section{Introduction}

The current village is expected to become a potential force that can contribute to strengthening the local economy in line with the hope of "Building Indonesia from the Outskirts by Strengthening Regions and Villages", according to these expectations, a commitment to oversee the implementation of the Village Law systematically, consistently and sustainably, to build the Village. advanced, strong, independent and democratic The village must be an economic force at the local level and have a global impact [1].

So far, the view of the village is a place of romanticism to remember childhood, which is usually visited once a year during the Eid homecoming. The village has not been able to offer attractiveness to its citizens who have migrated to the city to look for new livelihoods. The village as the previous constitution uses the norms in Law No. 5 of 1979 on Village Government and Law No. 32 of 2004 is the lowest government structure under the district. The village receives assistance assignments from the government, provincial government, district / city government. As a government organization that is in the district / city government system, the position of the village is the local state government[2]. 
Critical reflection on the "Village", at least represents the community's thoughts about the situation that occurred in the Village. Viewed from the point of view of the interests of the Village community, the opportunity for the Village to realize the common will in the spirit of the Village to build. The village appears as a subject that plans and sets its own development priorities, regardless of government or regional government instructions. Meanwhile, on the other hand, the feudal character and elitism of the Village Government administrators has the opportunity to emerge again [2]. In that context, democracy is needed to develop the social capital of the Village community in dealing with and managing Village power. Through democracy, it can be expected that awareness in the village community will grow about its position as the true source and owner of power. BUM Desa is a form of Village economic independence by mobilizing strategic business units for Village collective economic efforts. In fact, BUMDes is established and strengthened by the initiative of the village government which has the goal of optimizing and utilizing the economic potential and advantages of a village, wellmanaged economic institutions, and developing village potential with the aim of improving the welfare of the village community. The establishment of BUMDES is based on Law Number 6 of 2014 concerning Villages. Therefore, the implementation of BUMDes is supported by village funds provided by the government to support bumdes operations.

In line with this support, to help the problems of rural communities, through the management of local resources managed by the community is profit-oriented[2]. Every citizen of a community in a rural area will naturally have concrete social relations to form a social group, either based on ties based on economic, political or cultural / belief interests. defined in Article 1 point 6 of Law no. 6/2014 concerning Villages, as: "Village-Owned Enterprises, hereinafter referred to as BUMDesa, are business entities whose entire or most of the capital is owned by the Village through direct participation originating from separated Village assets to manage assets, services and other businesses. for the maximum welfare of the Village community. "The concept of Village Tradition is one of the fundamental ideas that accompanied the establishment of BUM Desa. The Berdesa tradition is parallel to the wealth of social and political capital and has an effect on the sustainability of BUM Desa. The core ideas of the Berdesa Tradition in establishing BUM Desa are:

1. BUM Desa needs social capital (cooperation, solidarity, trust, and the like) for business development that reaches out to a more inclusive and wider social network

2. BUM Desa evelops in inclusive politics through the praxis of Village Deliberations as the highest forum for the development of Village economic enterprises driven by BUM Desa.

3. BUM Desa is one form of Village economic business that is collective between the Village government and the Village community. The collective Village economic effort carried out by BUM Desa contains elements of social business and economic business.[3]

The following is the flow of the mechanism for the establishment and classification of Bumdes businesses that can be used as a reference for development according to the potential of each region. 


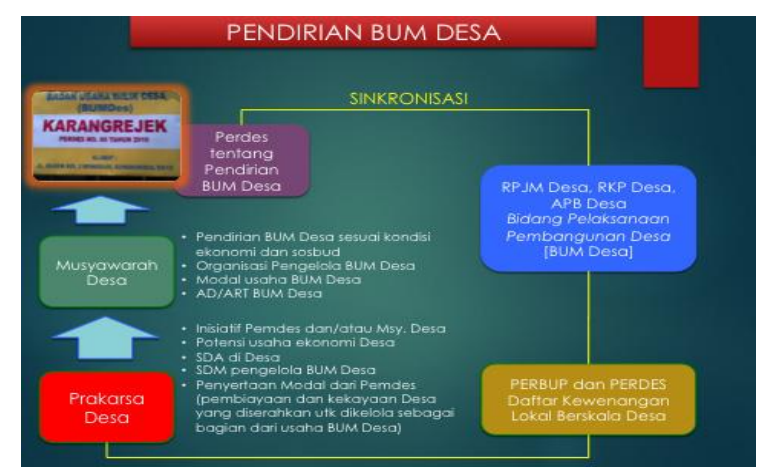

Fig.1. Bumdes establishment (Sumber: Anom Surya Putra (2015))

\begin{tabular}{|c|c|c|}
\hline Tipe & Deskripsi & Contoh \\
\hline Serving & $\begin{array}{l}\text { BUMDes menjalankan "bisnis sosial" yang } \\
\text { melayani warga, yakni dapat melakukan } \\
\text { pelayanan publik kepada masyarakat. Dengan } \\
\text { kalimat lain, BUMDes ini memberikan social } \\
\text { benefits kepada warga, meskipun tidak } \\
\text { memperoleh economic profit yang besar. }\end{array}$ & $\begin{array}{l}\text { - Usaha air minum desa, usaha } \\
\text { listrik desa, lumbung pangan. }\end{array}$ \\
\hline Banking & $\begin{array}{l}\text { BUMDes menjalankan "bisnis uang". yang } \\
\text { memenuhi kebutuhan keuangan masyarakat desa } \\
\text { dengan bunga yang lebih rendah daripada bunga } \\
\text { uang yang didapatkan masyarakat desa dari para } \\
\text { rentenir desa atau bank-bank konvensional }\end{array}$ & $\begin{array}{l}\text { - Bank desa atau lembaga } \\
\text { perkreditan desa atau lembaga } \\
\text { keuangan mikro desa }\end{array}$ \\
\hline Renting & $\begin{array}{l}\text { BUMDes menjalankan bisnis penyewaan untuk } \\
\text { melayani kebutuhan masyarakat setempat dan } \\
\text { sekaligus untuk memperoleh pendapatan desa. Ini } \\
\text { sudah lama berjalan di banyak di desa, terutama } \\
\text { desa-desa di lawa. }\end{array}$ & $\begin{array}{l}\text { - Penyewaan traktor, perkakas } \\
\text { pesta, gedung pertemuan, } \\
\text { rumah toko, tanah, dan } \\
\text { sebagainya. }\end{array}$ \\
\hline Brokering & $\begin{array}{l}\text { BUMDes menjadi "lembaga perantara" yang } \\
\text { menghubungkan komoditas pertanian dengan } \\
\text { pasar atau agar para petani tidak kesulitan } \\
\text { menjual produk mereka ke pasar. Atau BUMDes } \\
\text { menjual jasa pelayanan kepada warga dan usaha- } \\
\text { usaha masyarakat. }\end{array}$ & $\begin{array}{l}\text { - Jasa pembayaran listrik } \\
\text { - Desa mendirikan pasar desa } \\
\text { untuk memasarkan produk- } \\
\text { produk yang dihasilkan } \\
\text { masyarakat. }\end{array}$ \\
\hline Trading & $\begin{array}{l}\text { BUMDes menjalakan bisnis yang berproduksi } \\
\text { dan/atau berdagang barang-barang tertentu } \\
\text { untuk memenuhi kebutuhan masyarakat maupun } \\
\text { dipasarkan pada sekala pasar yang lebih luas. }\end{array}$ & $\begin{array}{l}\text { - Pabrik es, pabrik asap cair, hasil } \\
\text { pertanian, sarana produksi } \\
\text { pertanian, dll. }\end{array}$ \\
\hline Holding & $\begin{array}{l}\text { BUMDes sebagai "usaha bersama", atau sebagai } \\
\text { induk dari unit-unit usaha yang ada di desa, } \\
\text { dimana masing-masing unit yang berdiri sendiri- } \\
\text { sendiri ini, diatur dan ditata sinerginya oleh } \\
\text { BUMDes agar tumbuh usaha bersama. }\end{array}$ & $\begin{array}{l}\text { - Kapal desa yang berskala besar } \\
\text { untuk mengorganisir dan } \\
\text { mewadahi nelayan-nelayan } \\
\text { kecil. } \\
\text { - "Desa wisata" yang } \\
\text { mengorganisir berbagai jenis } \\
\text { usaha dari kelompok } \\
\text { masyarakat: makanan, } \\
\text { kerajinan, sajian wisata, } \\
\text { kesenian, penginapan, dll. }\end{array}$ \\
\hline
\end{tabular}

Fig. 2. Matrix 1 Bumdes Business Classification (Sumber: Sutoro Eko (2013))

Based on the matrix and figure above, it can be concluded that as a milestone in the local economy, BUMDes functions as a social and commercial institution. Efforts and strategies are needed to keep the wheels of the village economy moving. Local community business units are a potential strategy for rural empowerment. [4] The role of BUMDes as a village economic institution in a pandemic situation must think about ways and strategies in moving the village economy going forward, besides that through the business activities owned is by optimizing the resources owned by the village so that it can become the identity or selling value of a village, besides that during This BUMDES was also initiated with the hope of being able to provide job 
opportunities for residents, and, no less important, the overall goal of BUMDES is to increase village original income with various types of businesses run by BUMDes among units that can be used as opportunities, including savings and loans cooperatives, cooperatives agriculture to help farmers get loans and the ease of obtaining fertilizers or rice seeds, car rental for transporting goods to the city, management of clean water sources or hippam, management of village markets, as well as tourist villages and many others.

Based on data from the Ministry of Village, PDTT, BUMDes is showing better progress, proven to be 50,199 BUMDes units. [5] This shows that, almost 67 percent of rural areas already have business units in the village. PDTT Ministry of Village data also states that a total of 37,125 BUMDes are actively transacting. Among them, BUMDes which have the potential for tourism villages also dominate in various regions. And as a reference material also that in 2018, Indonesia already has nearly 1,734 potential tourism villages. This shows that strategic steps show an increase of 33 percent compared to 2014. Meanwhile, based on the distribution of the area, in almost the entire distribution of tourist villages, the most significant average of their existence is the tourist villages in the regions in Java and Bali.[6] but in other areas there are also potential tourism villages, among several villages that have well-known tourist villages, namely Ponggok Village in Klaten, Central Java, and Kutuh Village in Badung, Bali, the two villages have extraordinary achievements in harnessing tourism potential. village through the tourism BUMDes. Classically, the category of rural tourism is divided into two, namely directly related to rural space, closeness to nature, and several types of recreation. [5]

This tourism village is a village that has potential, These villages have enormous cultural, historic, artistic and architectural value[6], as well as its own uniqueness in the area of each village, to be used as a tourist attraction that can attract the attention of visitors, with the aim of making the community around the tourist village locations prosperous. This is inseparable from the concept of Community Based Tourism (CBT) which is always emphasized on village tourism, with key concepts of economic and social welfare, political empowerment for local communities, and friendly to local culture.

Local culture which has the potential of each being developed into the tourism sector must also be supported by a good understanding of the social networks that have been built in rural areas so far, this will greatly assist the mentoring processes carried out at the village community level. Starting from the development planning process to empowering village communities. Social networks in rural areas are one of the social capital which supports the existence of rural communities. This social network is built through social relationships, both formal and informal.

By maximizing the management of bumdes, it is hoped that the existence of BUMDes will be able to stimulate and revive the economic sector in rural areas. The potential economic assets in rural areas are managed by local residents so that they are expected to be able to optimize their potential. The substance and philosophy of BUMDes is actually able to motivate and motivate the spirit of togetherness and self-help as a strategic step to strengthen the institutional sector of the economy. so that BUMDes will later be able to align with its main objective, which is to be able to significantly increase village cash income, on the other hand it is also the driving force for the residents' economic sector, namely BUMDes as a forum or media for community economic activities. [7] 


\section{Methodology}

The author conducted a literature study by determining the topic of writing and determining the formulation of the problem. The literature review is a comprehensive overview of the research that has been done on specific topics to show readers what is already known about the topic and what is not known, to seek rationale for research that has been done or for ideas for further research. Literature studies are obtained from various sources including journals, books, documentation, internet and literature. The literature study method is a series of activities related to the methods of collecting library data, reading and taking notes, and managing writing materials. The type of writing used is a literature review study that focuses on the results of writing related to the topic or variable of writing including studies of villages and their potentials, bumdes and tourism villages.

\section{Finding and Discussion}

\subsection{Tourism Village Innovation}

The rural environment is an arrangement of various spatial physical elements as a space for activities and non-physical elements in the form of values in society. The existence of territory, population and life system are elements in forming Bintarto village (1977) The dynamic development of rural communities will be reflected in their physical formation and socio-cultural behavior. It can be concluded that discussing rural development cannot be separated from the perspective of village history and its aspects both physical, topography, geographic, environmental physical structure, governance in the landscape cannot be separated from knowledge of non-physical aspects (community activities, philosophical values, socioculture and politics). [8]. The following is one of the tourist villages in Jambu Tourism Village, Kayen Kidul District, Kediri Regency, Jambu Tourism Village is more famous for its tourism village which develops the concept of educational tourism, the tourism concept is also equipped with various vehicles with educational tourism concepts such as longan agro-tourism, million fish tourism., Niagara tubing tours (serinjing), rice planting tours, cow bathing tours, Kediri seedlings, ettawa goat tours, yogurt houses, reading gardens and roads with a million colors, wood waste processing education (ask craft), outbound games, grafting education and tabulampot. This is expected to be able to attract the community, whether it is paud, elementary school, to junior high school that can be used as educational tours. Of all the available rides, Bumdes Jaya Makmur Jambu and the Jambu Village Government as the manager of this tourism village of course also provide tickets for each vehicle. However, tickets for all rides are relatively cheap, not more than IDR 50,000, for each ride. [9] The following is documentation of various rides for Jambu Tourism Village: 


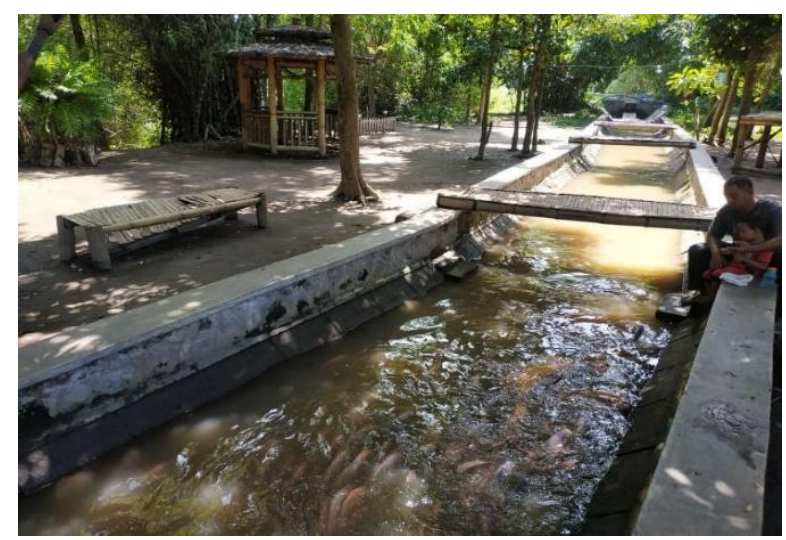

Fig. 3. One million fish tour (Sumber: Abdul Azis (2019))

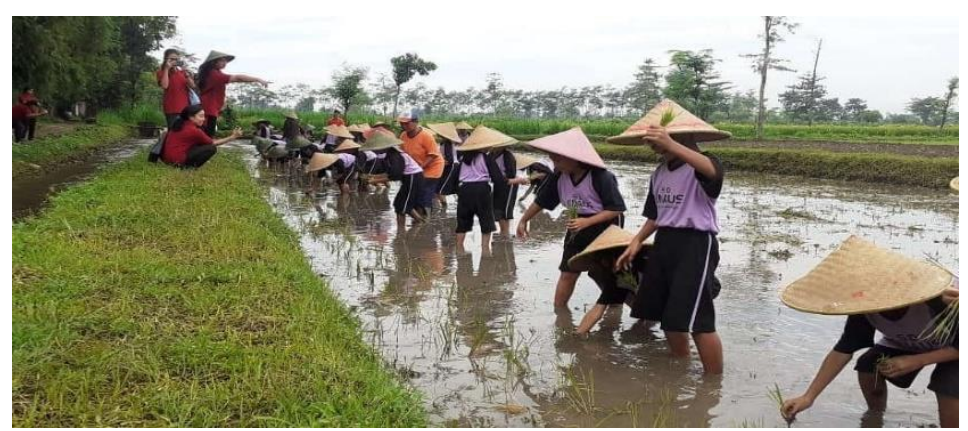

Fig. 4. Rice planting tour (Sumber: Abdul Azis (2019))

Concrete steps that can be taken by tourist villages to increase the chances of visiting millennial tourists are the use of technology. Collectively, tourist villages can create a digital platform called the tourism village electronic application or E-Dewi. This application serves as a provider of information, receipt of payments, and online interaction with managers. This opportunity is supported by data on the amount of technology utilization from hootsuite.com, which states 7,593 billion total population, 4,021 internet users, 3,196 billion active social media users, 5,135 unique mobile users, and 2.958 billion active mobile social users. Internet users in Indonesia according to Kominfo in 2018 are ranked in the top 6 in the world until 2018. Other sources at apji.or.id mention $143.26 \mathrm{M}$ internet users out of $262 \mathrm{M}$ Indonesia's population. The Ministry of Tourism in 2018 argues that $63 \%$ of traveling activities are currently being searched for, ordered and sold online and $50 \%$ of online travel sales use more than one gadget, even more than 200 reviews about traveling per minute have been posted on TripAvisor. Apart from promotional efforts and socialization through digitization, the importance of social networks. Building social networks and developing cooperation is an important and strategic agenda that must be well understood by village assistants. The following is a form of tourism promotion via Instagram : 


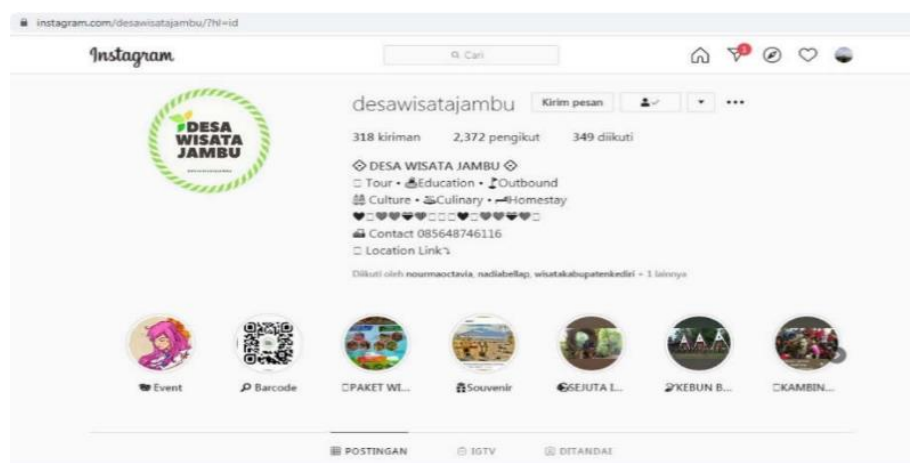

Fig. 5. Instagram account for Jambu tourism village (Sumber: Abdul Azis (2019))

\section{Accelerating The Improvement Of The Local Finance Through The Exploration Of Local Wisdom}

So far, we are familiar with the concept of living in a community, nation and state, but have not yet touched the village locus. The issuance of the Village Law has placed the village as a collective forum for state and community life, so that the concept of Village Tradition is created as a concept of community and state life in the realm of the Village.1 The core ideas of the Village Tradition are:

1. The village is the basis for social capital

It fosters a tradition of solidarity, cooperation, self-help and mutual cooperation in an inclusive manner that transcends the exclusive boundaries of kinship, ethnicity, religion, sect or the like.

2. The village has power and governance Which includes the authority and accountability to regulate and manage the interests of the community.

3. Villages exist as drivers of the local economy Those who are able to carry out the function of protection and distribution of basic services to the community,[10]

This principle is in line with what was conveyed that local wisdom is a community effort to conserve resources that can be used continuously for the community and maintain environmental balance. Community empowerment based on local wisdom through community participation in the development of tourism villages is an important factor in directing equitable development and meeting community needs. The development of a tourism village based on environmental preservation cannot be separated from the element of empowerment. The success of development can be measured through three main aspects namely the economic aspect to measure the added value in the community's economy, the social aspect to measure the community as a stakeholder in the management of a tourism village, and the environmental aspect to measure the impact of tourism from an environmental conservation perspective. This is also in line with what Campbell said, (1977). If a tourism is to be focused on aspects of sustainability, then the aspects that must be considered further are related to social, economic and environmental aspects.

The tourism village has the potential for a unique tourist attraction that is unique to its community of people who are able to create a combination of various tourist attractions and supporting facilities to attract tourist visits. There are components that form a tourist village, namely, as follows: 
1. Clear geographic or administrative boundaries.

2. Potential for natural, cultural and creative tourist attraction as an element to attract tourist visits.

3. The community is enthusiastic and supports the development of a tourist village.

4. Tourism facilities as a supporting element for tourists in carrying out tourist activities in the village (accommodation / homestay, food stalls managed by the community, tourist information centers and others).

5. Infrastructure facilities in the form of road networks, tourist transportation modes that support the convenience of tourists in reaching the village.

6. A tourism village management organization that functions as a tourism activity management unit in the village (planning, implementing, managing, evaluating/ monitoring development activities).

7. Human resources are the driving force for the management of tourism activities in the village. The development of a tourism village, it is important to know in advance the extent of the potential and developments that have occurred in a tourism village, so that strategies and programs can be formulated according to the level of development.

Based on the Tourism Life Cycle and Product Life Cycle, the level of development of a tourism village as a tourism product can be categorized into 3 (three) stages, namely potential, development, and progress. Meanwhile, the indicators for each stage are as follows:

- Potential:

At this level, a village is characterized by a potential that can be developed to become a tourist destination, the development of tourism infrastructure is still limited, there are no tourist visits, and public awareness of tourism potential has not yet grown.

- Developing

At this level, a village is characterized by being recognized and visited by tourists, there has been development of infrastructure and tourism facilities, creating jobs and economic activities for the local community, public awareness of tourism potential has begun to grow, and still requires assistance from related parties (government and private).

- Advanced

At this level, a village is characterized as having become a tourist destination that is known and visited by many tourists, tourism infrastructure and facilities are adequate, the community is independent and able to manage tourism businesses independently, a community that is fully aware of tourism potential, is able to build networks promotion and marketing independently or in collaboration with external parties, independently able to carry out capacity building activities internally (human resources, products, organizations, etc.), and can be a pilot model for the development of other tourist villages.

Rural tourism is broadly a form of tourism product developed in rural areas or areas (country side), as a form of tourism activity that brings tourists to experience and appreciate the uniqueness of life and traditions of rural communities with all their potential. A tourism village in the context of rural tourism can be called a tourism asset based on rural potential with all its uniqueness and attractiveness that can be empowered and developed as a tourism product to 
attract tourist visits to the village location. Sustainable tourism development is meeting the needs of tourists today and protecting the potential of the village and increasing opportunities for the future. This encourages the management of owned resources so that they can meet economic, social and aesthetic needs while maintaining cultural integrity, important ecological processes, biodiversity and life support systems. UNEP (2002). [10] The following is the flow of rural tourism to the stage of being able to serve local products:

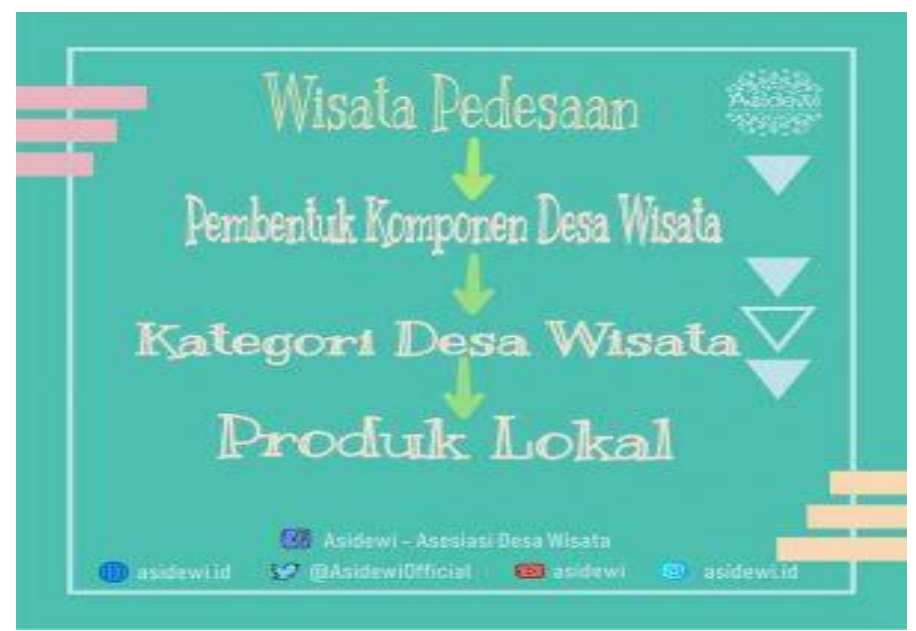

Fig. 6. Stages of Determining Local Products (Sumber: Asidewi)

The uniqueness of an area gives a deep impression on the attraction of tourists, which will automatically accelerate the economic development of the village. [11] n connection with the principle of developing a Tourism Village, the important thing to pay attention to is the Product aspect. Products in terms of tourism, hereinafter referred to as tourism products, are an important component in tourism planning and development. can be divided into 3 (three), namely core products, supporting products, and complementary products. The products offered must have authenticity, come from the traditions of the local community, community involvement in producing local products, the products offered come from local attitudes and values, and do not damage the surrounding environment. The following are some of the tourism village products offered, the beach Kutang is located in Labuhan Village, Brondong District, Lamongan Regency, where this village is able to change what used to be the beach that was not maintained and there was a lot of underware (kutang) so to make it easier to remember its history it was called Kutang Beach. [12] The uniqueness of this beach is the sand structure. Because in general, the area surrounded by mangrove forests is in the form of mud, but on this beach it is a stretch of white sand. As well as the view of the high seas, it is also more complete with the existence of a rainbow bridge that is built across the coast. The wooden bridge with a colorful paint finish is a special favorite for tourists. From the top of this $\pm 1 \mathrm{~km}$ long bridge, tourists can see the underwater beauty. Many tourists take advantage of the rainbow bridge to take pictures. [12] The following is documentation of the beauty of Kutang Beach: 


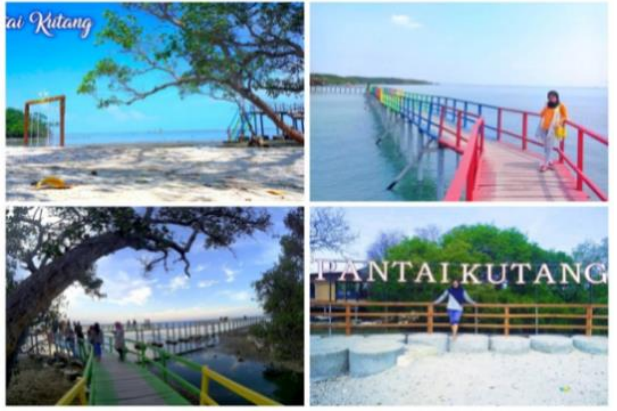

Fig. 7. Pantai Kutang (Sumber: Yunita (2020))

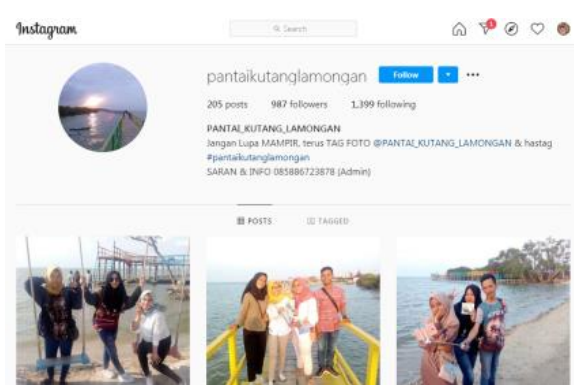

Fig. 8. Akun Instagram Pantai Kutang (Sumber: Yunita (2020))

Next, the village of Wisata Puncak Tapan Andongsari, Grabagan District, Tuban Regency, the tourism village was initiated to optimize the improvement of the village economy by utilizing empty land with all its limitations because the road access to this location is still a lot of damage and limited lighting, but pokdarwis succeeded in changing the top of the village. be an interesting vehicle [13] The following is the documentation of the peak tour of Wisata Puncak Tapan Andongsari:

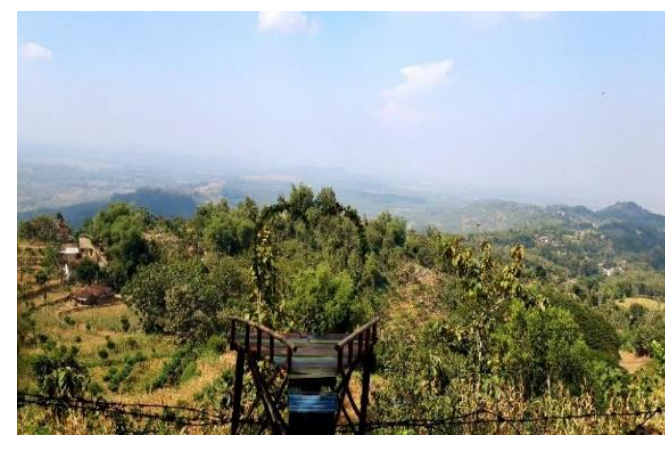

Fig. 9. Wisata Puncak Tapan Andongsari Sumber: Bagas Purnama (2019)

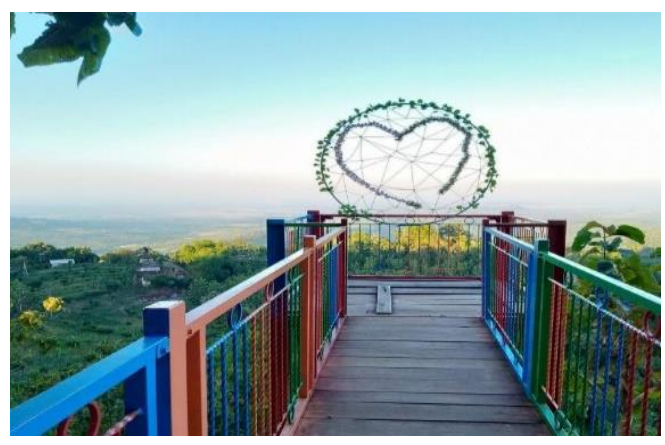

Fig. 10. Spot rides Sumber: Bagas Purnama (2019)

Based on the exploration of guava tourism village, kutang tourism village and wind tapan tourism village, it can be concluded that: creative tourism as a creative economy that produces "knowledge-based creative activities that combine the needs of tourists by utilizing regional potential by utilizing technology, talent, or skills to produce rides and tourist attractions to experience creative experiences "OECD (2014) [14] Design decisions need to be based on user intentions and experiences and holistic approaches to problems and opportunities; combine imagination, creativity and science for effective innovation; and recognize that stories, especially of the users, are an important tool in the design process [15].

Tourism development through tourism village will be able to answer critics against tourism that are categorized capitalistic and not pro-people. At least, there are huge potential of tourism, it will give direct With village tourism development, community has wide opportunity to participate in every step of development; any kinds of local knowledge and local wisdom, will become important inputs in tourism planning and tourism management; local community are 
able to optimize asset usage and resources for economic activities; conservation of culture and village environment will be more naintained [10].

Beside the direct advantages, there are some indirect impacts that are received by community of the village related with village tourism development, such as transportation infrastructure improvement, development of utilities and facilities of health and sanitation, development of micro industry in the village, etc.[10]. The following is one of the benefits that can be felt, such as the ones we document below:

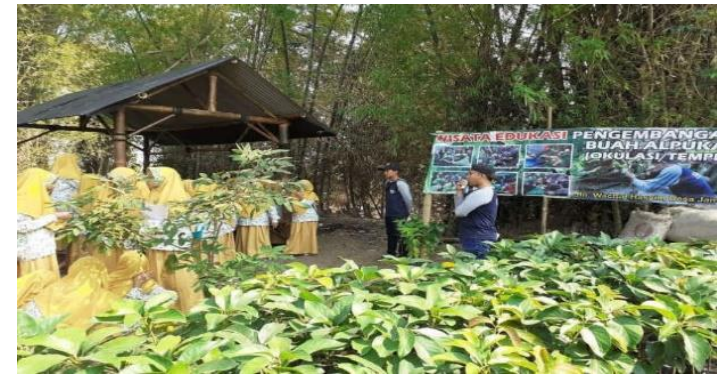

Fig. 11. Jambu Tourism village nursery Sumber: Abdul Azis (2019)

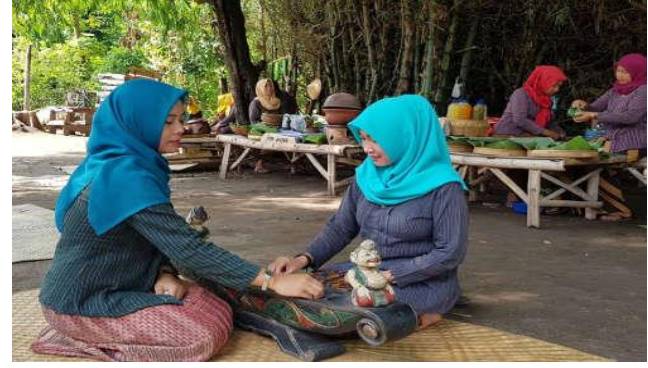

Fig. 12. Pasar Papringan Jambu Tourism village Sumber: Abdul Azis (2019)

This documentation can be explained that the nursery is an effort to conserve the environment through introduction of fruit seeds and grafting education. And the preservation of traditional culinary culture by presenting a natural market concept under the shady village atmosphere. Many aspects of creativity and contemporary culture now fall under the UNWTO (2018) definition of cultural tourism, which includes "arts and architecture, historical and cultural heritage, culinary heritage, literature, music, creative industries and the living cultures with their lifestyles, value systems, beliefs and traditions." This suggests significant integration of the creative economy and cultural tourism. UNWTO research shows that $81 \%$ of National Tourism Administrations consider 'contemporary culture and creativity' (film, performing arts, design, fashion, new media, etc.) as part of cultural tourism.

Exploring the potential of villages that can be developed requires social capital (cooperation, solidarity, trust, and commitment) for business development that reaches more inclusive and broader social networks to produce tourism village designs. With the active involvement of the village community through pokdarwis and encouraged through the awareness of the village community to have a commitment to develop the village's potential, the village will be able to drive the village economy.

\section{Conclusion}

Villages have potential strengths that can contribute to strengthening the economy if managed properly. The establishment of BUM Desa is one form of Village economic independence by mobilizing strategic business units for Village collective economic efforts. For this reason, BUMDes is strengthened on the initiative of the village government which aims to optimize and utilize the economic potential and advantages of a village, well-managed economic institutions, and the development of village potential with the aim of improving the welfare of the village community. The establishment of BUMDES is based on Law Number 6 
of 2014 concerning Villages. Therefore, the implementation of BUMDes is supported by village funds provided by the government to support bumdes operations. BUM Desa development is part of community empowerment objective. Desa can establish an enterprise called BUM Desa which is intended to render village's economic potential and empower local people for the sake of community welfare. According to this rule, village can use the fund received to support the economic operation for BUM Desa to promote community empowerment.The purposes of BUM Desa establishment are to improve the village economy and public services, manage village potential, create market and jobs, and increase business and income of the village community.tourists began visiting places in small groups that focused on the experience of nature and culture driving factor about local wisdom upheld to maintain the rural environment which is the trademark of the tourist village.

Acknowledgements. This paper is written based on research studies from and literature reviews on village tourism. The author would like to thank Abdul Azis, Bagas Purnama, Yunita who inspired this paper.

\section{References}

[1] N. Amanulloh, Demokratisasi Desa. Jakarta: Kemeneterian Desa, Pembangunan Daerah Tertinggal, dan Transmigrasi Republik Indonesia, 2015.

[2] S. Eko, T. I. Khasanah, D. Widuri, S. Handayani, and N. Handayani, Desa Membangun Indonesia. FPPD. Yogyakarta, 2014.

[3] B. Arifin et al., "Village fund, village-owned-enterprises, and employment: Evidence from Indonesia," J. Rural Stud., vol. 79, pp. 382-394, 2020.

[4] "No Title.", [Online]. Available: http://xn--httpshw3b//bebas.kompas.id/baca/riset/2020/06/26/momentum-kebangkitan-bumdes-dimasapandemi/?utm_source=external_kompascom\&utm_medium=berita_terkini\&utm_cam paign=kompascom.”.

[5] F. Randelli and F. Martellozzo, "Is rural tourism-induced built-up growth a threat for the sustainability of rural areas? The case study of Tuscany," Land use policy, vol. 86, pp. 387-398, 2019, doi: 10.1016/j.landusepol.2019.05.018.

[6] J. Gao and B. Wu, "Revitalizing traditional villages through rural tourism: A case study of Yuanjia Village, Shaanxi Province, China," Tour. Manag., vol. 63, pp. 223-233, 2017, doi: 10.1016/j.tourman.2017.04.003.

[7] M. Nursan and A. F. Utama FR, "STRATEGI PENGEMBANGAN BADAN USAHA MILIK DESA (BUMDES) BERBASIS PERTANIAN DI KABUPATEN SUMBAWA BARAT," J. soc. econ. agric., vol. 8, no. 2, p. 67, 2019, doi: 10.26418/j.sea.v8i2.37726.

[8] V. R. Vitasurya, "Local wisdom for sustainable development of rural tourism, case on kalibiru and lopati village, province of daerah istimewa Yogyakarta," Procedia Soc. Behav. Sci., vol. 216, pp. 97-108, 2016, doi: 10.1016/j.sbspro.2015.12.014.

[9] M. A. Azis and M. Meirinawati, "MANAJEMEN STRATEGI PENGEMBANGAN WISATA EDUKASI DI DESA JAMBU KECAMATAN KAYEN KIDUL KABUPATEN KEDIRI," Publika, vol. 8, no. 4, 2020.

[10] G. K. Sutawa, "Issues on Bali tourism development and community empowerment to support sustainable tourism development," Procedia econ. Financ., vol. 4, pp. 413-422, 
2012, doi: 10.1016/s2212-5671(12)00356-5.

[11] W. Astuti, Qomarun, A. Febela, R. A. Putri, and D. W. Astuti, "Identification of specific characteristic of kampung jayengan as community-based industrial tourism," Procedia Soc. Behav. Sci., vol. 227, pp. 485-492, 2016, doi: 10.1016/j.sbspro.2016.06.104.

[12] Y. D. P. Sari, "STRATEGI PENGEMBANGAN WISATA PANTAI KUTANG DI DESA LABUHAN KECAMATAN BRONDONG KABUPATEN LAMONGAN," publika, 2020.

[13] M. B. Purnama, "STRATEGI PENGEMBANGAN WISATA PUNCAK TAPAN ANDONGSARI OLEH BUMDES NGANDONG JAYA MAKMUR DI DESA NGANDONG KECAMATAN GRABAGAN KABUPATEN TUBAN," publika, vol. 8 , no. 5 , p. $55,2020$.

[14] G. Richards, "Designing creative places: The role of creative tourism," Ann. Tour. Res., vol. 85, no. 102922, p. 102922, 2020, doi: 10.1016/j.annals.2020.102922.

[15] G. Moscardo, "Stories and design in tourism," Ann. Tour. Res., vol. 83, no. 102950, p. 102950, 2020, doi: 10.1016/j.annals.2020.102950. 